\title{
Analisis Kemampuan Pemecahan Masalah Mahasiswa pada Mata Kuliah Teori Bilangan
}

\author{
Erwan Setiawan', Guntur Maulana Muhammad2*, dan Muhamad Soeleman ${ }^{3}$ \\ 1,2*3Program Studi Pendidikan Matematika, Universitas Suryakancana \\ Jalan Dr. Muwardi, Komplek Pasir Gede Raya, Cianjur, Jawa Barat, Indonesia \\ 1erwan@unsur.ac.id, 2*guntur@unsur.ac.id,33uhamadsoeleman@unsur.ac.id
}

Artikel diterima: 28-02-2020, direvisi: 28-09-2020, diterbitkan: 31-01-2021

\begin{abstract}
Abstrak
Teori bilangan merupakan cabang matematika yang mempelajari sifat-sifat dan hubungan dari suatu bilangan bulat. Untuk dapat memahami materi teori bilangan dengan baik maka dibutuhkan kemampuan pemecahan masalah yang baik pula. Penelitian ini bertujuan untuk mengetahui kemampuan pemecahan masalah matematika mahasiswa pada mata kuliah teori bilangan. Subjek penelitian yaitu 26 mahasiswa program studi pendidikan matematika, FKIP, Universitas Suryakancana tingkat I tahun ajaran 2017-2018. Data penelitian yang dikaji adalah lembar jawaban mahasiswa pada Ujian Tengah Semester tahun ajaran 2017-2018. Dengan metode deskriptif kuantitatif, didapatkan hasil secara umum yang menerangkan bahwa kemampuan pemecahan masalah mahasiswa program studi pendidikan matematika FKIP Universitas Suryakancana dapat dikategorikan "cukup" (64,62\%). Lebih rinci, kemampuan mahasiswa dalam merencanakan penyelesaian masalah dapat dikategorikan "baik", dengan persentase $74,62 \%$ namun sayangnya kemampuan dalam melakukan pengecekan kembali adalah yang paling lemah, dapat dikategorikan "kurang" dengan persentase $54,62 \%$. Hal ini yang nantinya akan menjadi dasar evaluasi dalam perbaikan pembelajaran.

Kata Kunci: Kemampuan Pemecahan Masalah, Mahasiswa, Teori Bilangan
\end{abstract}

\section{College Students' Problem-Solving Skills Analysis on Number Theory Course}

\begin{abstract}
Number theory is a branch of mathematics that studies the properties and relationships between an integer. Understanding the material studied in number theory well also requires good mathematical problem-solving skills. This research aims to determine college students' problem-solving skills in a number theory course. The research subjects were 26 students in the mathematics education program, FKIP, Suryakancana University level I in the 2017-2018 school year. The research data used is the student answer sheet in the Middle Semester Examination in the 2017-2018 school year. By the quantitative descriptive method, the results of the research were that the problem-solving skills of students, in the mathematics education program, FKIP, Suryakancana University, can be categorized as fair (64.62\%). Specifically, the students' skill to plan problem-solving can be categorized as good (74.62\%) but the validating conclusion is the weakest one that can be categorized as poor (54.62\%). This will underlie the evaluation in improving learning.

Keywords: College student, Number theory, Problem-solving skill.
\end{abstract}




\section{Pendahuluan}

Teori Bilangan merupakan cabang ilmu matematika yang mempelajari sifat-sifat, hubungan, dan jenis-jenis bagian dari bilangan. Dari berbagai himpunan bilangan yang dipelajari di dalam teori bilangan, yang paling penting adalah himpunan bilangan bulat positif (Rosen, 2011). Hasil kunci dari teori bilangan menunjukkan bahwa bilangan prima merupakan faktor pembentuk bilangan bulat positif. Hal ini termuat dalam teorema fundamental aritmatika yang mengatakan bahwa setiap bilangan bulat secara unik dapat ditulis sebagai perkalian beberapa bilangan prima.

Salah satu penerapan teori bilangan adalah dalam Kriptografi. Kriptografi dikaitkan dengan proses mengubah teks biasa menjadi teks yang tidak dapat dipahami dan sebaliknya (Bennet, 2018). Ini adalah metode penyimpanan dan transmisi data dalam bentuk tertentu sehingga hanya mereka yang dimaksudkan dapat membaca dan memprosesnya. Penerapan lain dari teori bilangan adalah Kalender Abadi. Dengan menggunakan algoritma kalender abadi, dapat ditentukan nama hari untuk sembarang tanggal dan tahun yang diberikan. Dari contoh-contoh penerapan teori bilangan di atas memberikan gambaran tentang pentingnya ilmu ini untuk dipelajari.

Dalam kurikulum pendidikan tinggi, khususnya yang berlaku di program studi Pendidikan Matematika, Universitas Suryakancana, Mata Kuliah Teori Bilangan merupakan mata kuliah wajib dengan bobot 3 sks. Perlunya Teori Bilangan dipelajari oleh mahasiswa salah satunya karena terdapat teorema-teorema penting di dalamnya yang harus diketahui oleh mahasiswa. Di pendidikan tinggi, mahasiswa mengalami fase-fase belajar yang mengarah pada pengembangan pengetahuan, pengubahan pola pikir ke arah logis dan realistis, serta pembiasaan diri untuk lebih mandiri. Sehingga diharapkan mahasiswa yang telah lulus dari pendidikan tinggi memiliki pengetahuan yang lebih dalam suatu bidang ilmu dengan mengedepankan rasionalitas dan memiliki karakter seorang yang mandiri (Muhammad \& Karso, 2018).

Dalam mempelajari teori bilangan, tentunya dibutuhkan beberapa kemampuan berpikir matematis diantaranya kemampuan pemecahan masalah. Karena jika dilihat dari tujuan perkuliahan teori bilangan, mahasiswa harus sering dihadapkan dengan permasalahan - permasalahan matematis. Terbiasanya mahasiswa menghadapi masalah, maka akan terbiasa pula mahasiswa dalam memecahkan masalah tersebut. Hal ini disebabkan "pemecahan masalah" bukan hanya suatu tujuan pembelajaran matematika tapi juga menjadi sarana utama untuk melakukannya (Muhammad et al., 2018). Perlu diketahui bahwa tujuan perkuliahan mata kuliah teori bilangan adalah mahasiswa diharapkan memiliki kemampuan membuktikan suatu pernyataan atau proposisi dalam matematika. Selain itu juga diharapkan 
mahasiswa memiliki pola berpikir yang kritis, logis dan sistematis, serta kreativitas (Afriansyah, dkk., 2020) dalam pemecahan masalah. Dan tidak hanya itu, mahasiswa juga memiliki kemampuan membaca dan menggunakan informasi secara mandiri dari sumber-sumber belajar, khususnya buku teks, untuk dapat menyelesaikan masalah-masalah terkait. Pada akhirnya, tujuan yang paling matematis adalah mahasiswa memiliki pengetahuan mengenai sifat-sifat bilangan, hubunganhubungan antar bilangan, jenis-jenis bagian dari bilangan.

Berdasarkan National Council of Teacher of Mathematics (NCTM) dan Peraturan Menteri Pendidikan Nasional Republik Indonesia Nomor 69 Tahun 2013 tentang standar isi, salah satu kemampuan matematis yang harus dimiliki peserta didik dalam pembelajaran matematika adalah kemampuan pemecahan masalah matematis (problem solving). Sesuatu dikatakan masalah ketika ada kesenjangan antara situasi saat ini dengan tujuan yang akan dicapai. Ketika ada aturan tertentu yang dapat mengatasi kesenjangan tersebut, maka dapat dikatakan masalah terpecahkan (Widodo, 2013; Kurniawati \& Rizkianto, 2018). Pemecahan masalah berawal dari situasi yang perlu adanya sebuah penyelesaian (Tisngati, 2015; Afriansyah, 2016; Albab, Saputro, \& Nursyahidah, 20).

Menurut Bohan, salah satu tujuan pemecahan masalah matematika adalah meningkatkan kemampuan untuk memilih solusi dengan strategi yang tepat (Novianti et al., 2017; Latifah \& Luritawaty, 2020). Pemecahan masalah dapat memberikan keuntungan bagi peserta didik dalam belajar matematika. Hal ini dikarenakan kemampuan pemecahan masalah mendorong munculnya kreativitas, fleksibilitas, dan berpikir metakognitif yang sesuai dengan kebutuhan-kebutuhan profesional dan kebutuhan dalam kehidupan sehari-hari (Prabawanto, 2013).

Akan tetapi tidak mudah mengembangkan kemampuan pemecahan masalah dengan tingkat kesulitan masalah yang tinggi, karena pada pendidikan tinggi masalah semakin kompleks. Dosen sebagai pengajar harus mendorong mahasiswanya untuk merefleksikan pemikiran mereka selama proses pemecahan masalah agar dapat mengadaptasikan suatu ide pada konteks yang lain (Samo, 2017).

Polya (Polya, 1973) mengajukan empat langkah fase penyelesaian masalah yaitu memahami masalah, merencanakan penyelesaian, menyelesaikan masalah dan melakukan pengecekan kembali semua langkah yang telah dikerjakan. Fase memahami masalah bisa dikatakan sebagai fase identifikasi. Dalam fase ini peserta didik diharapkan mampu mengidentifikasi masalah yang ada dan mengetahui gejala atau faktor penyebab timbulnya permasalahan. Setelah fase memahami masalah dilalui dengan baik, proses berikutnya adalah melakukan perencanaan terkait penyelesaian masalah. Dalam pembuatan perencanaan 
penyelesaian masalah informasi terkait gejala atau faktor penyebab timbulnya masalah menjadi sesuatu yang penting agar pemilihan metode penyelesaian masalahnya lebih efektif dan efisien. Fase berikutnya adalah menyelesaikan masalah sesuai rencana yang telah disusun sebelumnya. Dan terakhir adalah fase pengecekan kembali atau fase validasi. Dalam fase ini, setiap fase pemecahan masalah dilakukan evaluasi untuk mengetahui kekurangan yang ada sehingga proses perbaikan bisa dilakukan.

Terkait dengan kemampuan pemecahan masalah, banyak penelitianpenelitian awal atau prasyarat yang menganalisis kemampuan pemecahan masalah siswa SMP atau SMA. Namun sangat sedikit sekali yang menggunakan mahasiswa sebagai subjek penelitiannya. Padahal sama seperti siswa SMP atau SMA, tidak semua mahasiswa pada program studi pendidikan matematika sudah memiliki kemampuan pemecahan masalah yang baik. Terkadang masih ada saja yang membutuhkan perhatian lebih dari pengajarnya, khususnya di perguruan tinggi swasta.

Beberapa penelitian terkait kemampuan pemecahan masalah siswa SMP dan SMA diantaranya yang dilakukan oleh Asih (2019), mereka menyatakan bahwa fakta di sekolah menunjukkan kemampuan pemecahan masalah matematika siswa masih tergolong rendah. Ada juga yang menyatakan bahwa dengan model Problem Based Learning dapat meningkatkan kemampuan pemecahan masalah menjadi lebih baik (Suryani \& Jufri, 2020). Lebih dari itu, penelitian tentang kemampuan pemecahan masalah siswa sudah pada tahap menentukan korelasinya dengan gaya belajar dan kemandirian belajar. Perbedaan gaya belajar tidak mempengaruhi kemampuan pemecahan masalah, tapi kemandirian belajar mempengaruhi kemampuan pemecahan masalahnya (Darma et al., 2016; Sundayana, 2018).

Tujuan dari penelitian ini adalah untuk mengetahui kemampuan pemecahan masalah mahasiswa pada mata kuliah teori bilangan.

\section{Metode}

Metode penelitian yang digunakan adalah metode deskriptif kuantitatif, yaitu suatu metode dalam meneliti status sekelompok manusia, suatu objek, suatu set kondisi, suatu sistem pemikiran ataupun suatu kelas peristiwa pada masa sekarang (Nazir, 2009). Subjek penelitian adalah mahasiswa program studi pendidikan matematika FKIP Universitas Suryakancana yang mengambil mata kuliah teori bilangan pada tahun akademik 2017-2018. Jumlah mahasiswa yang menjadi subjek penelitian sebanyak 26 orang. Data penelitian yang dikaji dalam penelitian ini yaitu lembar jawaban mahasiswa pada Ujian Tengah Semester (UTS) tahun akademik 2017 - 2018. Waktu pelaksanaan UTS adalah pada hari Rabu tanggal 04 April 2018 di program studi 
pendidikan matematika FKIP Universitas

Suryakancana.

Instrumen penelitian yang digunakan dalam penelitian ini adalah tes yang disusun agar mahasiswa menjawab berdasarkan 4 indikator pemecahan masalah. Empat indikator tersebut meliputi kemampuan memahami permasalahan melalui identifikasi unsurunsur yang diketahui; kemampuan merencanakan penyelesaian melalui pemilihan strategi pemecahan masalah yang tepat; kemampuan menyelesaikan masalah melalui proses perhitungan yang tepat dan benar; dan kemampuan melakukan pengecekan (validasi) kembali untuk memastikan kesimpulan yang diambil sudah benar.

Jenis tes yang digunakan dalam penelitian ini adalah tes subjektif, yaitu umumnya berbentuk tes uraian dimana peserta didik dalam menjawab soal tersebut dilakukan dengan cara mengekspresikan pikiran peserta tes (Wijoyoko, 2011). Dengan jenis tes seperti ini mahasiswa bisa mengeksplorasi pengetahuannya semaksimal mungkin, walaupun dengan batasan-batasan tertentu. Contoh tes subjektif matematis seperti soal berikut, "Buktikan bahwa semua bilangan berbentuk $5^{n}-1$ akan habis dibagi 4 untuk $\in \mathbb{N}$ !".

Penilaian tes evaluasi akhir mengacu kepada pedoman penskoran yang diadaptasi dari Vermont Math Problem Solving Criteria, Vermont Department of
Education (Mawaddah \& Anisah, 2015) yang ditunjukkan pada Tabel 1 berikut:

Tabel 1.

Pedoman Penskoran Kemampuan Pemecahan Masalah

\begin{tabular}{|c|c|c|}
\hline Indikator & $\begin{array}{l}\text { Respon terhadap } \\
\text { soal/masalah }\end{array}$ & Skor \\
\hline $\begin{array}{l}\text { Memahami } \\
\text { masalah }\end{array}$ & $\begin{array}{c}\text { Ada upaya } \\
\text { mengidentifikasi } \\
\text { unsur-unsur yang } \\
\text { diketahui, ditanyakan, } \\
\text { tetapi masih kurang } \\
\text { tepat } \\
\text { Dapat } \\
\text { mengidentifikasi } \\
\text { unsur-unsur yang } \\
\text { diketahui, ditanyakan } \\
\text { untuk memperoleh } \\
\text { bagian dari } \\
\text { penyelesaian tetapi } \\
\text { masih kurang lengkap } \\
\text { Identifikasi unsur } \\
\text { lengkap dan benar }\end{array}$ & 2 \\
\hline $\begin{array}{c}\text { Merencanakan } \\
\text { penyelesaian }\end{array}$ & $\begin{array}{c}\text { Strategi yang dibuat } \\
\text { kurang relevan dan } \\
\text { mengarah pada } \\
\text { jawaban yang salah } \\
\text { Strategi yang dibuat } \\
\text { sudah tepat }\end{array}$ & 2 \\
\hline $\begin{array}{c}\text { Menyelesaikan } \\
\text { masalah }\end{array}$ & $\begin{array}{c}\text { Ada penyelesaian } \\
\text { masalah tetapi masih } \\
\text { salah } \\
\text { Penyelesaian masalah } \\
\text { ada, tetapi masih } \\
\text { terdapat kekeliruan } \\
\text { dalam perhitungan } \\
\text { Penyelesaian masalah } \\
\text { benar }\end{array}$ & 3 \\
\hline $\begin{array}{c}\text { Melakukan } \\
\text { pengecekan } \\
\text { kembali }\end{array}$ & $\begin{array}{c}\text { Kesimpulan yang } \\
\text { diberikan kurang } \\
\text { tepat } \\
\text { Kesimpulan yang } \\
\text { diberikan tepat }\end{array}$ & 2 \\
\hline
\end{tabular}

Keterangan:

Skor = 0 bila tidak ada respon atau jawaban kosong untuk setiap kriteria.

Nilai minimal $=0$, dan Nilai maksimal $=10$ 


\section{Hasil dan Pembahasan}

Hasil penskoran yang dilakukan terhadap hasil jawaban mahasiswa dapat dilihat pada Gambar 1.

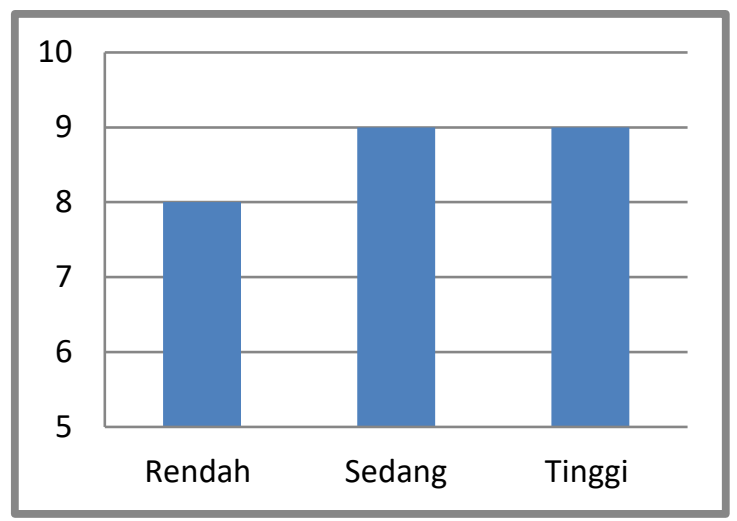

Gambar 1. Distribusi frekuensi kemampuan pemecahan masalah matematis mahasiswa.

Dari 26 mahasiswa responden didapat data bahwa sebanyak 8 mahasiswa memiliki kemampuan pemecahan masalah yang masih rendah, 9 mahasiswa kemampuannya sedang, dan 9 mahasiswa kemampuannya tinggi. Dari data ini dapat diambil kesimpulan sebanyak kurang lebih 69\% mahasiswa dapat menyelesaikan permasalahan-permasalahan yang berkaitan dengan mata kuliah teori bilangan dengan cukup baik.

Adapun kemampuan rata-rata mahasiswa untuk setiap indikator kemampuan pemecahan masalah dapat dilihat dalam Tabel 2. Dari Tabel 2 terlihat bahwa secara umum kemampuan awal mahasiswa, yaitu memahami masalah dan merencanakan penyelesaian, sudah cukup baik. Hal ini menggambarkan secara umum mahasiswa mempunyai potensi yang cukup bagus untuk dapat menyelesaikan berbagai masalah yang berkaitan dengan teori bilangan secara khusus maupun yang berkaitan dengan kehidupan sehari-hari. Akan tetapi, potensi yang cukup bagus ini belum ditunjang dengan kemampuan perhitungan yang baik sehingga pembuatan kesimpulan masih keliru.

Tabel 2.

Rata-rata Kemampuan Pemecahan Masalah Mahasiswa Berdasarkan Indikator

\begin{tabular}{|clcc|}
\hline No & $\begin{array}{c}\text { Indikator } \\
\text { Pemecahan } \\
\text { Masalah }\end{array}$ & $\begin{array}{c}\text { Rata- } \\
\text { Rata }\end{array}$ & Kualifikasi \\
\hline 1 & $\begin{array}{l}\text { Memahami } \\
\text { masalah }\end{array}$ & $70,00 \%$ & Baik \\
\hline 2 & $\begin{array}{l}\text { Merencanakan } \\
\text { penyelesaian }\end{array}$ & $74,62 \%$ & Baik \\
\hline 3 & $\begin{array}{l}\text { Menyelesaikan } \\
\text { masalah }\end{array}$ & $59,23 \%$ & Cukup \\
\hline 4 & $\begin{array}{l}\text { Melakukan } \\
\text { pengecekan } \\
\text { kembali }\end{array}$ & $54,62 \%$ & Kurang \\
\hline
\end{tabular}

$$
\text { Rata-rata 64,62\% }
$$

Terlihat pada Tabel 2 bahwa kemampuan perhitungan dan validasi (pengecekan kembali) yang dibawah 60\% menunjukkan bahwa secara umum mahasiswa belum terlatih dalam melakukan perhitungan sehingga seringkali melakukan kesalahan mendasar dalam melakukan perhitungan.

Selain berdasarkan indikator kemampuan pemecahan masalah, penelitian ini juga memaparkan hasil yang ditinjau dari setiap soal. Pada soal nomor 1 (Gambar 2), kemampuan mahasiswa yang dominan terlihat adalah pada kemampuan identifikasi masalah dan kemampuan pemilihan strategi pemecahan masalah. 


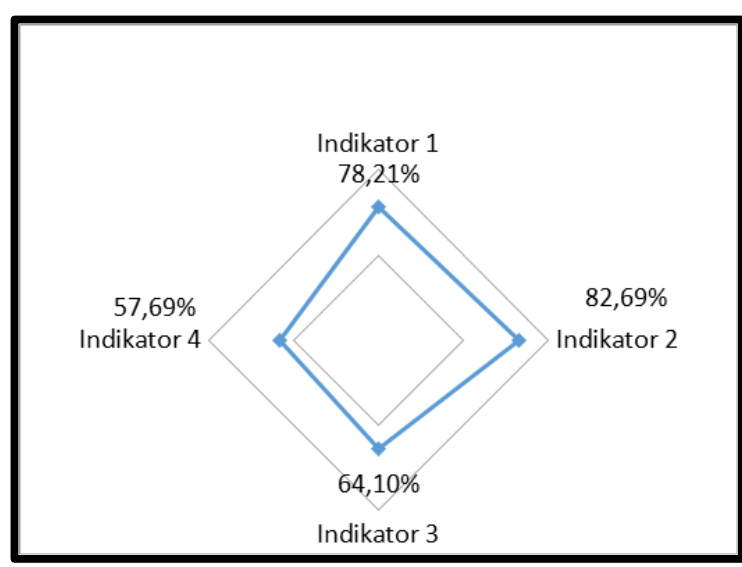

Gambar 2. Kemampuan Pemecahan Masalah Mahasiswa pada Soal Nomor 1.

Kemampuan lain yang cukup baik yaitu dalam melakukan perhitungan lebih dari 64\% sudah benar, akan tetapi dapat dilihat juga bahwa yang melakukan validasi kurang lebih 58\% artinya hanya 6\% yang tidak melakukan validasi sehingga kesimpulan yang diambilpun menjadi kurang tepat. Pada dasarnya memang soal dengan tipe "pembuktian" ini menjadi soal yang dianggap susah menurut persepsi mahasiswa, karena seringkali mereka merasa kebingungan harus memulai dari mana. Hal ini sesuai juga dengan pernyataan Muhammad, bahwa sebagian besar mahasiswa masih mengalami kesulitan dalam menjawab soal pembuktian atau belum terampil dalam membuktikan suatu teorema/proposisi. Kesalahan yang sering terjadi adalah dalam pengaplikasian konsep / teorema / pengetahuan sebelumnya untuk menunjukkan suatu hal yang belum terbukti kebenarannya (Muhammad, 2017).

Pada soal nomor 2 (Gambar 3), pola kemampuan pemecahan masalah mahasiswa yang terlihat memiliki pola yang sama seperti pada soal nomor 1 .

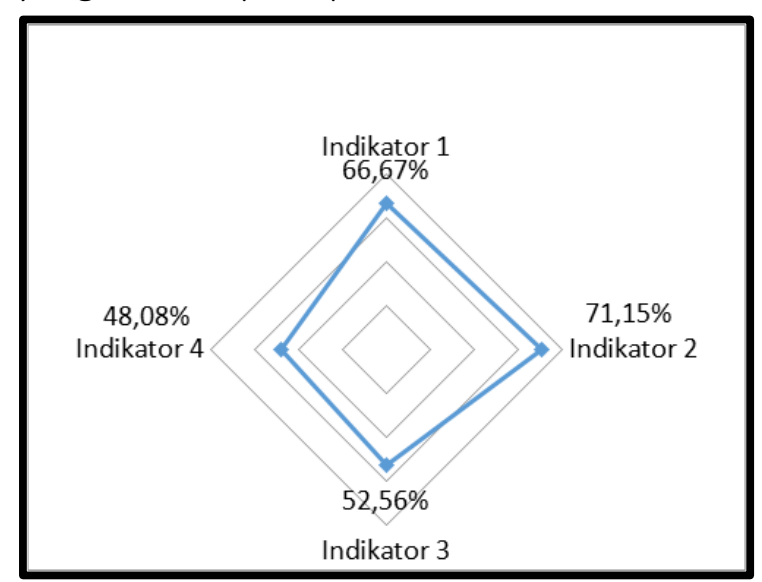

Gambar 3. Kemampuan Pemecahan Masalah pada Soal Nomor 2.

Perbedaan yang terlihat adalah pada persentase penguasaannya saja. Kemampuan pemecahan masalah pada soal nomor 2 persentase penguasaannya lebih rendah dibandingkan pada soal nomor 1. Hal ini menunjukkan bahwa soal nomor 2 memiliki tingkat kesulitan yang lebih tinggi dari pada soal nomor 1.

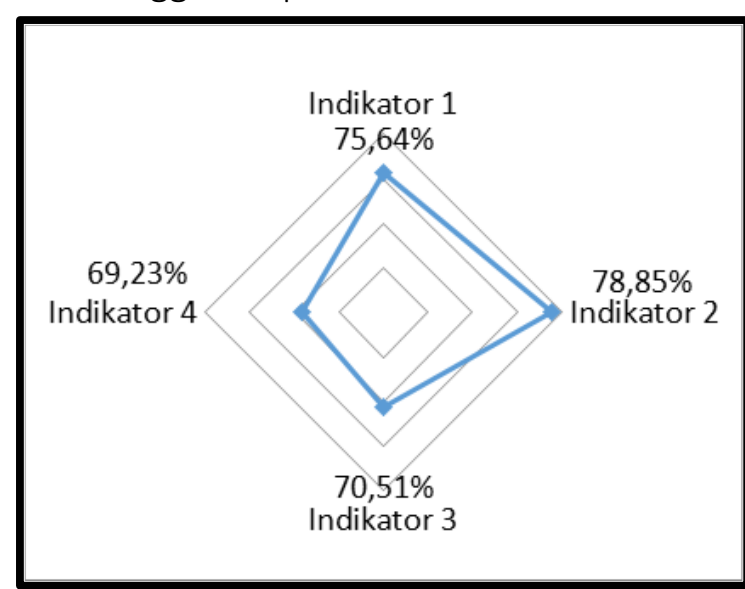

Gambar 4. Kemampuan Pemecahan Masalah pada Soal Nomor 3.

Kemampuan pemecahan masalah pada soal nomor 3 (Gambar 4) terlihat lebih merata untuk setiap indikatornya. Setiap indikator kemampuan pemecahan 
masalah yang dikuasai mahasiswa mencapai lebih dari 60\%. Dengan demikian tipe masalah atau soal pada nomor 3 cukup dapat diselesaikan dengan baik oleh mahasiswa.

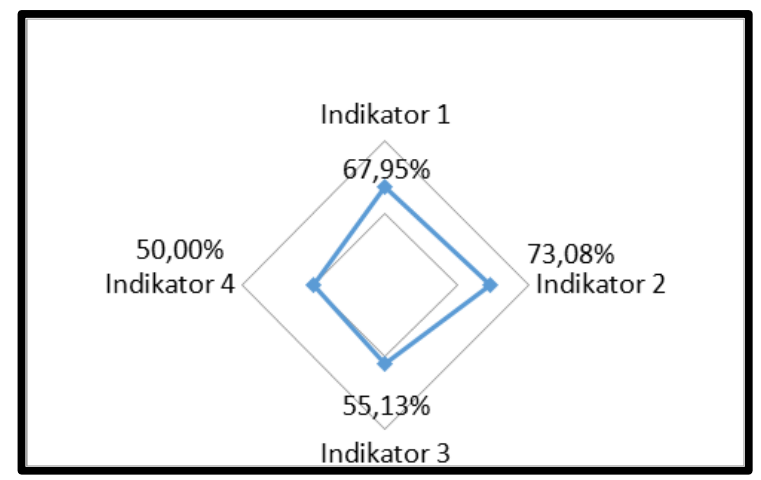

Gambar 5. Kemampuan Pemecahan Masalah pada Soal Nomor 4.

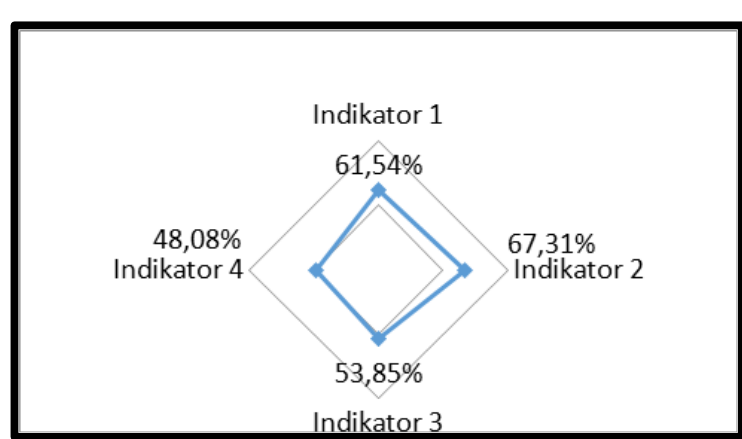

Gambar 6. Kemampuan Pemecahan Masalah pada

Soal Nomor 5.

Untuk soal nomor 4 dan nomor 5 pola sebaran indikator pemecahan masalahnya memiliki kemiripan, dapat dilihat pada Gambar 5 dan Gambar 6. Indikator yang dominan yaitu indikator identifikasi masalah dan indikator pemilihan strategi pemecahan masalah sedangkan indikator perhitungan dan indikator validasi dan penarikan kesimpulan masih rendah yaitu dibawah 60\%.
Berikut ini akan diuraikan beberapa kesalahan yang dilakukan oleh mahasiswa dalam menjawab soal-soal tes.

\begin{tabular}{l} 
1. $5^{n}-1$ akan habis dibagk nit \\
adb $P(n) n=1$ \\
$5^{-1}-1=4$ Terbukt \\
anggap $n=k$ \\
$5^{k}-1$ \\
Habris dibagi 4 \\
adb $n=k+1$ \\
$5^{k+1}-1$ \\
$5^{k}-1+5^{k+1}-1$ \\
$5^{k+1}+1$ \\
Habis dibar 4 \\
\hline
\end{tabular}

Gambar 7. Jawaban salah mahasiswa X pada soal nomor 1

Dari Gambar 7 terlihat bahwa mahasiswa X sudah dapat memahami permasalahan dengan baik diantaranya dapat melakukan identifikasi unsur-unsur yang diketahui dengan lengkap. Strategi penyelesaian masalah yang akan digunakan juga sudah tepat yaitu menggunakan induksi matematika. Akan tetapi dalam proses penyelesaian masalah masih terdapat kekeliruan, yaitu proses perhitungan $5^{k+1}-1$ menjadi $5^{k}-1+$ $5^{k+1}-1$. Terlihat mahasiswa $X$ tidak menguasai dengan baik terkait operasi aljabar khususnya operasi aljabar dalam bentuk perpangkatan. 


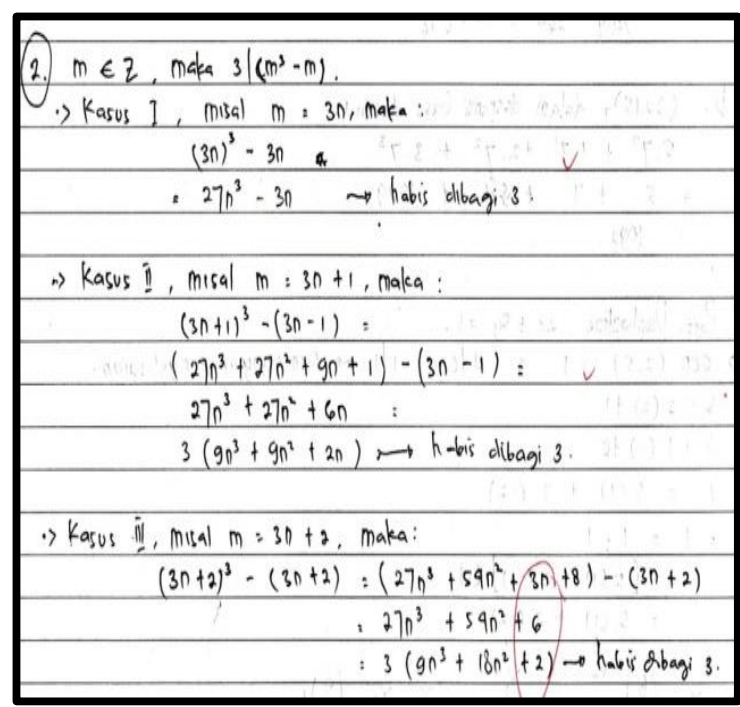

Gambar 8. Jawaban salah mahasiswa Y pada soal nomor 2.

Pada Gambar 8 terlihat mahasiswa $Y$ telah dapat melakukan identifikasi unsurunsur yang diketahui dengan lengkap dan strategi penyelesaian masalahnya pun sudah tepat. Kesalahan yang dilakukan adalah pada proses perhitungan dalam menyelesaikan masalah, yaitu pada bagian penguraian bentuk $(3 n+2)^{3}$. Terlihat mahasiswa $Y$ menguraikan bentuk $(3 n+2)^{3}$ menjadi $27 n^{3}+54 n^{2}+3 n+$ 8 seharusnya bentuk yang benar adalah $27 n^{3}+54 n^{2}+36 n+8$.

Perhatikan Gambar 9 di bawah. Secara umum terlihat mahasiswa Z sudah benar dalam melakukan penyelesaian masalah, baik dalam hal identifikasi unsur-unsur yang diketahui maupun dalam pemilihan strategi penyelesaian masalah. Akan tetapi ada kesalahan dalam perhitungan pada bagian $5.7^{0}$. Pada jawaban mahasiswa $Z$ terlihat $5.7^{0}=0$, hal ini tentu keliru karena $7^{0}=1$, sehingga bentuk yang benar adalah $5.7^{0}=5.1=5$.

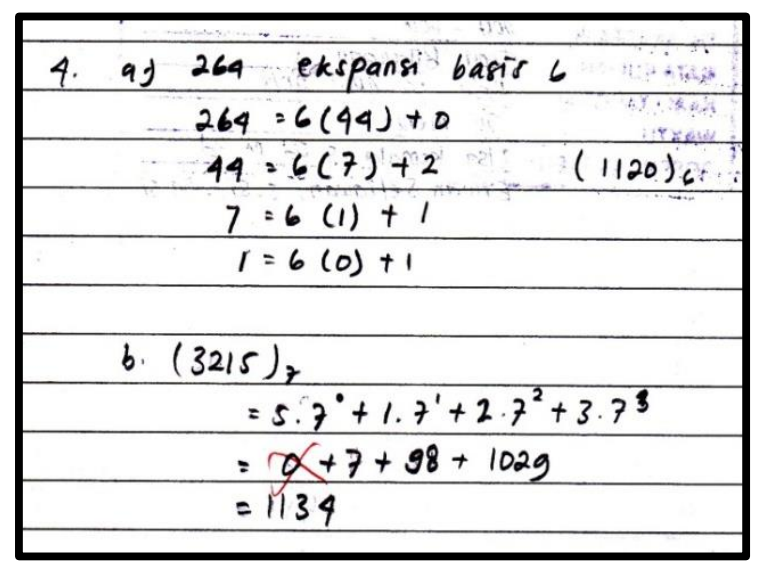

Gambar 9. Jawaban salah mahasiswa Z pada soal nomor 4

Secara umum, pada setiap tipe soal mahasiswa sudah dapat melakukan perencanaan untuk penyelesaian, akan tetapi saat eksekusi penyelesaian masalah tidak sedikit yang masih keliru. Artinya bisa jadi eksekusinya yang keliru atau saat perencanaannya yang masih belum benar. Kedua kemungkinan masih ada karena kelima soal tidak sejenis, cara penyelesaiannya berbeda-beda. Walaupun soal yang digunakan bukan soal cerita, tapi menerjemahkan soal dengan banyak simbol matematika merupakan kesulitan tersendiri yang bisa membuat mahasiswa menjadi ceroboh. Karena kecerobohan, kurangnya pemahaman, dan kata-kata asing merupakan kesulitan-kesulitan dalam menerjemahkan masalah (Cruz \& Lapinid, 2014). Kemudian faktor lain yang mempengaruhi kemampuan pemecahan masalah adalah kecemasan matematis. Kecemasan matematis ini yang nantinya akan membedakan cara berpikir divergen dan konvergen (Ningsih, 2016).

Hasil penelitian menunjukkan bahwa kemampuan pemecahan masalah 
mahasiswa terkategori "cukup", artinya secara rata-rata indikator kemampuan pemecahan masalahnya pun "cukup". Sehingga benar seperti yang diungkapkan Sariningsih, bahwa untuk meningkatkan kemampuan memecahkan masalah perlu dikembangkan keterampilan pada setiap indikatornya (Sariningsih \& Purwasih, 2017).

\section{Penutup}

Dari hasil penelitian dan pembahasan diperoleh kesimpulan bahwa kemampuan pemecahan masalah mahasiswa dalam mata kuliah teori bilangan tergolong dalam kategori "cukup" dengan indikator kemampuan pemecahan masalah yang paling dominan adalah kemampuan merencanakan penyelesaian masalah yaitu sebesar 74,62\%. Selain itu, indikator kemampuan pemecahan masalah yang masih kurang adalah indikator penyelesaian masalah melalui proses perhitungan yang benar dan tepat, dan indikator validasi kesimpulan yang diambil, dimana secara berurut-turut memiliki persentase penguasaan sebesar 59,23\% dan 54,62\%. Dengan kesimpulan ini kita mengetahui kondisi mahasiswa, kelemahan dan kelebihan mahasiswa dalam kemampuan pemecahan masalah. Sehingga hal ini bisa mendasari langkah selanjutnya yang harus dilakukan agar kelemahan mahasiswa dapat diperbaiki, dan kelebihannya bisa ditingkatkan.

\section{UCAPAN TERIMA KASIH}

Terima kasih kami ucapkan kepada Pimpinan FKIP - Universitas Suryakancana karena telah memberikan pendanaan penelitian ini.

\section{Daftar Pustaka}

Afriansyah, E. A. (2016). The Use of Realistic Approach to Enhance Students' Mathematical ProblemSolving Skills. In International Conference on Elementary and Teacher Education ICETE.

Afriansyah, E. A., Herman, T., Turmudi, T., \& Dahlan, J. A. (2020). Mendesain Soal Berbasis Masalah untuk Kemampuan Berpikir Kritis Matematis Calon Guru. Mosharafa: Jurnal Pendidikan Matematika, 9(2), 239-250.

Albab, I. U., Saputro, B. A., \& Nursyahidah, F. (2017). Peningkatan kemampuan pemecahan masalah matematis mahasiswa melalui collaborative analysis of sample student responses. Mosharafa: Jurnal Pendidikan Matematika, 6(1), 35-44.

Asih, N. (2019). Peningkatan Kemampuan Pemecahan Masalah Matematis dan Kemandirian Belajar Siswa Menggunakan Model Pembelajaran Means End Analysis. Jurnal Pendidikan Matematika, 8(3), 435-446.

Cruz, J. K. B., \& Lapinid, M. R. C. (2014, March 6). Students' difficulties in translating worded problems into mathematical symbols. DLSU Research Congress, Manila. 
Darma, Y., Firdaus, M., \& Haryadi, R. (2016). Hubungan Kemandirian Belajar Terhadap Kemampuan Pemecahan Masalah Matematis Mahasiswa Calon Guru Matematika. 14(1), 169-178.

Kurniawati, V., \& Rizkianto, I. (2018). Pengembangan Perangkat Pembelajaran Matematika Berbasis Guided Inquiry dan Learning Trajectory Berorientasi pada Kemampuan Pemecahan Masalah. Mosharafa: Jurnal Pendidikan Matematika,7(3), 369380.

Mawaddah, S., \& Anisah, H. (2015). Kemampuan Pemecahan Masalah Matematis Siswa pada Pembelajaran Matematika dengan Menggunakan Model Pembelajaran Generatif (Generative Learning) di SMP. 3(2), 166-175.

Muhammad, G. M. (2017). Analisis Kemampuan Penalaran Matematis Mahasiswa Pada Mata Kuliah Struktur Aljabar II (Teori Gelanggang). PRISMA, 6(1), 66-78.

Muhammad, G. M., \& Karso, K. (2018). Penerapan Model Guided Discovery Learning Untuk Meningkatkan Pemahaman Konsep Matematis Mahasiswa. Jurnal Eksakta Pendidikan (JEP), 2(2), 108.

Muhammad, G. M., Septian, A., \& Sofa, M. I. (2018). Penggunaan Model Pembelajaran Creative Problem Solving untuk Meningkatkan
Kemampuan Pemecahan Masalah Matematis Siswa. Mosharafa: Jurnal Pendidikan Matematika, 7(3), 315326.

Nazir, M. (2009). Metode Penelitian. Ghalia Indonesia.

Ningsih, E. F. (2016). Proses Berpikir Mahasiswa dalam Pemecahan Masalah Aplikasi Integral Ditinjau dari Kecemasana Belajar Matematika (Math Anxiety). Iqra, 1(2), 191-216.

Novianti, D. E., Khoirotunnisa', A. U., \& Indriani, A. (2017). Profil Pemecahan Masalah Matematika Dalam Menyelesaikan Permasalahan Pemrograman Linear Ditinjau Dari Kemampuan Komunikasi Matematis. JIPM, 6(1), 53-59.

Polya, G. (1973). How to Solve It. A New Aspect of Mathematical Method (2nd ed). Princeton University Press.

Prabawanto, S. (2013). Peningkatan Kemampuan Pemecahan Masalah, Komunikasi dan Self-Efficacy Matematis Mahasiswa Melalui pembelajara dengan Pendekatan Metacognitive Scaffolding [Disertasi]. UPI.

Rosen, K. H. (2011). Elementary number theory and its applications (6th ed). Addison-Wesley.

Samo, D. D. (2017). Kemampuan pemecahan masalah matematika mahasiswa tahun pertama dalam memecahkan masalah geometri konteks budaya. Jurnal Riset 
Pendidikan Matematika, 4(2), 141152.

Sariningsih, R., \& Purwasih, R. (2017).

Pembelajaran Problem Based Learning untuk Meningkatkan Kemampuan Pemecahan Masalah Matematis dan Self Efficacy Mahasiswa Calon Guru. JNPM (Jurnal Nasional Pendidikan Matematika), 1(1), 163-177.

Sundayana, R. (2018). Kaitan antara Gaya Belajar, Kemandirian Belajar, dan Kemampuan Pemecahan Masalah Siswa SMP dalam Pelajaran Matematika. Mosharafa: Jurnal Pendidikan Matematika, 5(2), 75-84.

Suryani, M., \& Jufri, L. H. (2020). Analisis Kemampuan Pemecahan Masalah Siswa Berdasarkan Kemampuan Awal Matematika. Mosharafa: Jurnal Pendidikan Matematika, 9(1), 119130.

Tisngati, U. (2015). Proses Berpikir Reflektif Mahasiswa dalam Pemecahan Masalah pada Materi Himpunan Ditinjau dari Gaya Kognitif Berdasarkan Langkah Polya. Jurnal Beta, 8(2), 115-124.

Zakiyah, S., Hidayat, W., \& Setiawan, W. (2019). Analisis Kemampuan Pemecahan Masalah dan Respon Peralihan Matematik dari SMP ke SMA pada Materi SPLTV. Mosharafa: Jurnal Pendidikan Matematika,8(2), 227238.

Widodo, S. A. (2013). Analisis Kesalahan Dalam Pemecahan Masalah

Divergensi Tipe Membuktikan pada
Mahasiswa Matematika. 46(2), 106113.

Wijoyoko, S. E. P. (2011). Evaluasi Program

Pembelajaran. Pustaka Belajar.

\section{Riwayat Hidup Penulis}

\section{Erwan Setiawan, S.Si., M.Si.}

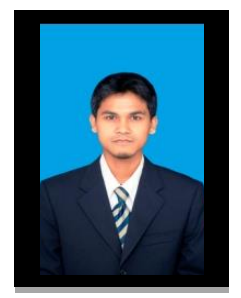

Lahir di Sukabumi, 26 Desember 1985. Staf pengajar pada Program Studi Pendidikan Matematika, Universitas Suryakancana. Studi S1 Matematika di Universitas Padjadjaran, Bandung, lulus tahun 2008; dan S2 Matematika di Universitas Indonesia, Depok, lulus tahun 2014.

\section{Guntur Maulana Muhammad, S.Pd., M.PMat.}

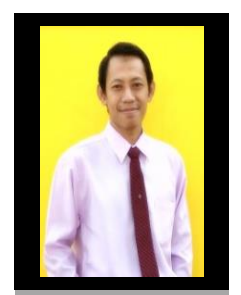

Lahir di Cianjur, 23 Oktober 1987. Staf pengajar pada Program Studi Pendidikan Matematika, Universitas Suryakancana. Studi S1 Pendidikan Matematika di Universitas Suryakancana, Cianjur, lulus tahun 2012; dan S2 Pengajaran Matematika di ITB, Bandung, lulus tahun 2015.

\section{Muhamad Soeleman, S.Pd., M.PMat.}

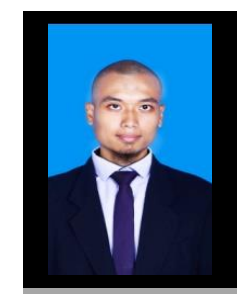

Lahir di Jakarta, 11 Februari 1989. Staf pengajar pada Program Studi Pendidikan Matematika, Universitas Suryakancana. Studi S1 Pendidikan Matematika di Universitas Negeri Jakarta, lulus tahun 2013; dan S2 Pengajaran Matematika di ITB, Bandung, lulus tahun 2015. 